\title{
A case of macrodystrophia lipomatosa presenting with pain
}

\author{
*Sarika Bhimrao Gaikwad ${ }^{1}$, Punam Vijay Uke ${ }^{1}$, Keerti Manish Swarnkar ${ }^{2}$, Rupesh Rao $^{3}$
}

Sri Lanka Journal of Child Health, 2021; 50(1): 159-161

DOI: http://dx.doi.org/10.4038/sljch.v50i1.9420

(Key words: Macrodystrophia lipomatosa, pain, MRI, debulking)

\section{Introduction}

Macrodystrophia lipomatosa (ML) is a noninherited developmental abnormality, resulting in the overgrowth of mesenchymal elements such as bones, fat, phalanges, nerves, tendons, and vessels and usually presenting at birth ${ }^{1,2}$. Involvement is commonly unilateral with the lower limbs more commonly involved than the upper limbs ${ }^{2}$. The second and third digits of the hands and feet are frequently involved ${ }^{2}$.

\section{Case report}

A 10 year old girl presented with a complaint of swelling of right foot and middle 3 toes since birth. Initially the swelling was small and gradually increased and attained the present size. The swelling was not painful initially, but for the last 6 months patient had pain in the right medial side of the foot while walking. Patient also had difficulties in playing and putting on her footwear which hampered day to day activities. Pain did not radiate to any joint. Birth and developmental histories were normal. There was no family history of similar complaints or of a neuro-cutaneous syndrome. On examination, swelling was present on right foot with swelling of all toes but especially on second, third and fourth toes (Figure 1)

On palpation, the toes were bulky and tender with firm skin on plantar aspect of the enlarged toes. There were no overlying skin alterations or pitting oedema and no signs suggestive of a neurocutaneous marker. Rest of the systemic examination was normal. Plain radiography of the right foot revealed enlarged second, third and fourth toes and hypertrophy/enlargement of phalanges of $3^{\text {rd }}$ toe (Figure 2).

${ }_{1}^{1}$ Assistant Professor, ${ }^{2}$ Professor, ${ }^{3}$ Junior Resident, Department of Paediatrics, Jawaharlal Nehru Medical College and Datta Meghe Medical Institute of Medical Science, India.

*Correspondence: drsudarshan5555@gmail.com

https://orcid.org/000-0003-3145-6628

(Keceived on 16 April 2020: Accepted after revision on 22 May 2020)

The authors declare that there are no conflicts of interest Personal funding was used for the project.

Open Access Article published under the Creative Commons

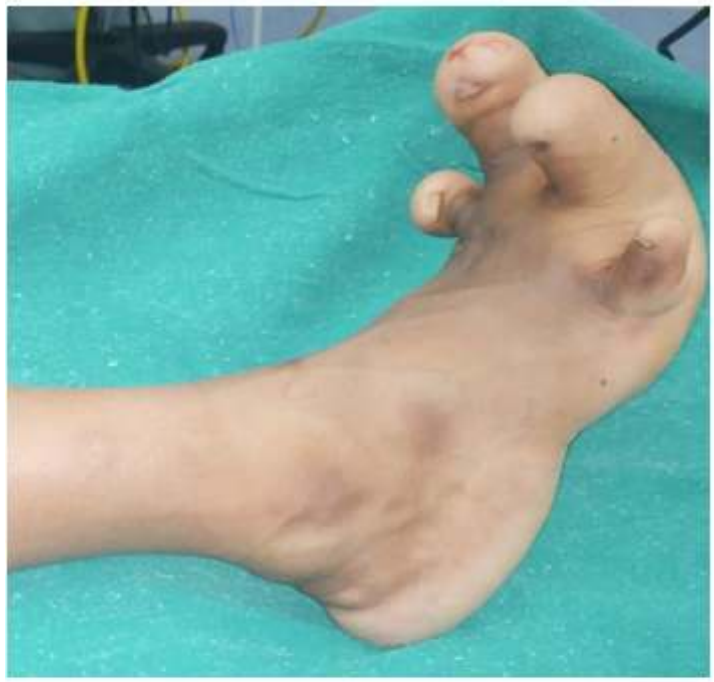

Figure 1: Anterior aspect of foot showing swelling of 3 toes

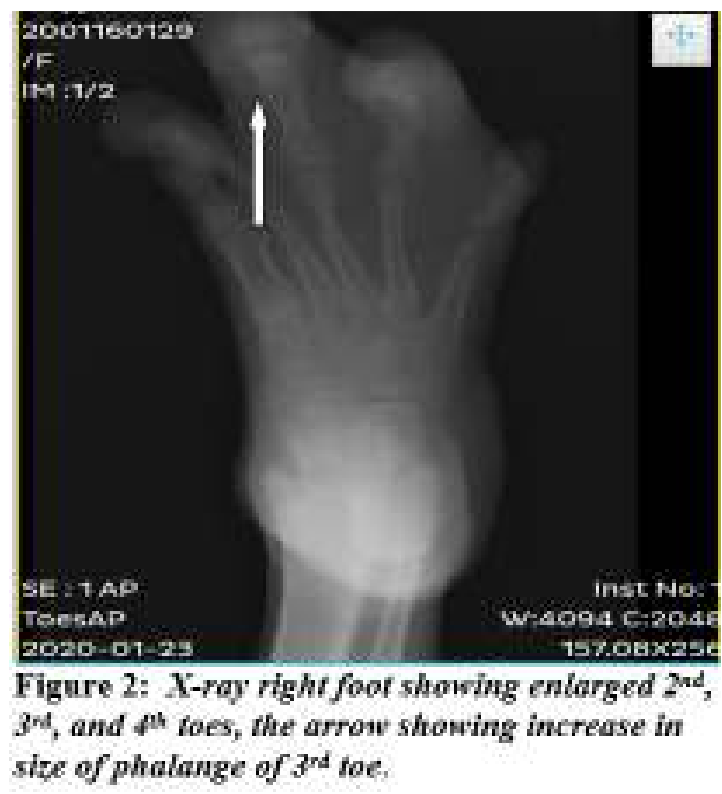

Magnetic resonance imaging (MRI) was suggestive of accumulation of fat in subcutaneous tissue, fat being predominantly present in the plantar aspect of right foot suggestive of ML (Figure 3,) without involvement of joints, ligaments, tendons and nerve sheath. 


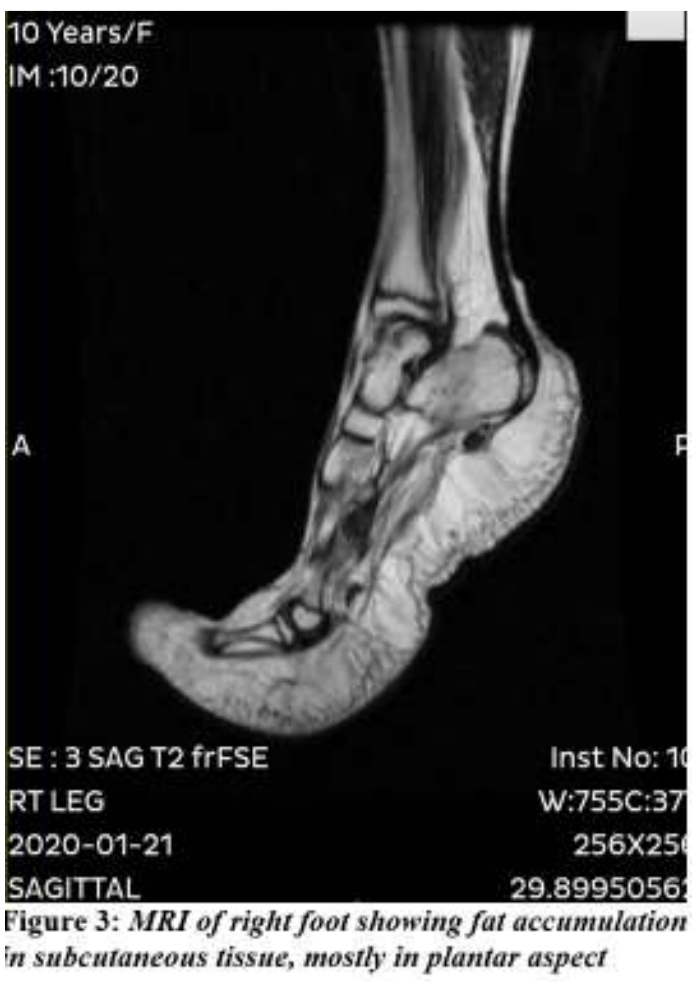

After confirmation of the diagnosis plastic surgical opinion was obtained and they advised surgical management which included debulking surgery and cosmetic surgery. Patient could not afford the cosmetic surgery and hence debulking surgery with amputation of middle three toes was done and fatty tissues were removed (Figure 4). Tissue sample was sent for histopathological examination. The histopathology was suggestive of the presence of mature fibro-adipose tissue without any involvement of the nerve sheath (Figure 5)

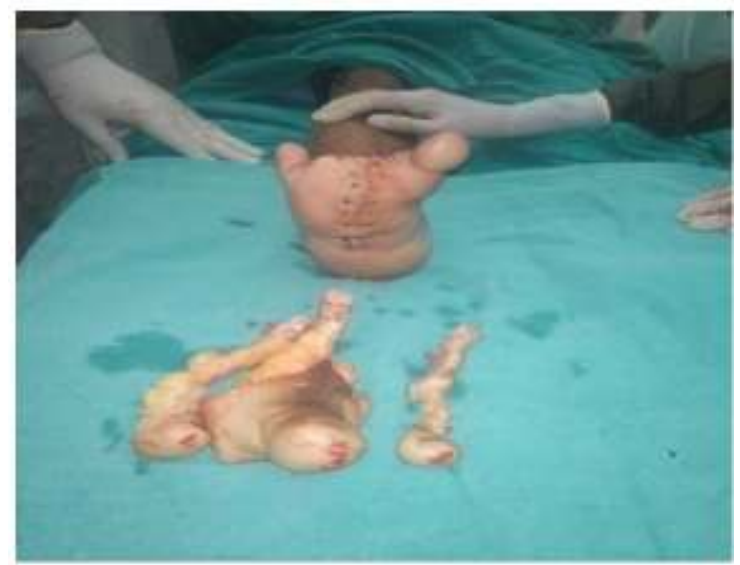

Figure 4: Amputation of middle three toes was done and fatty tissues were removed

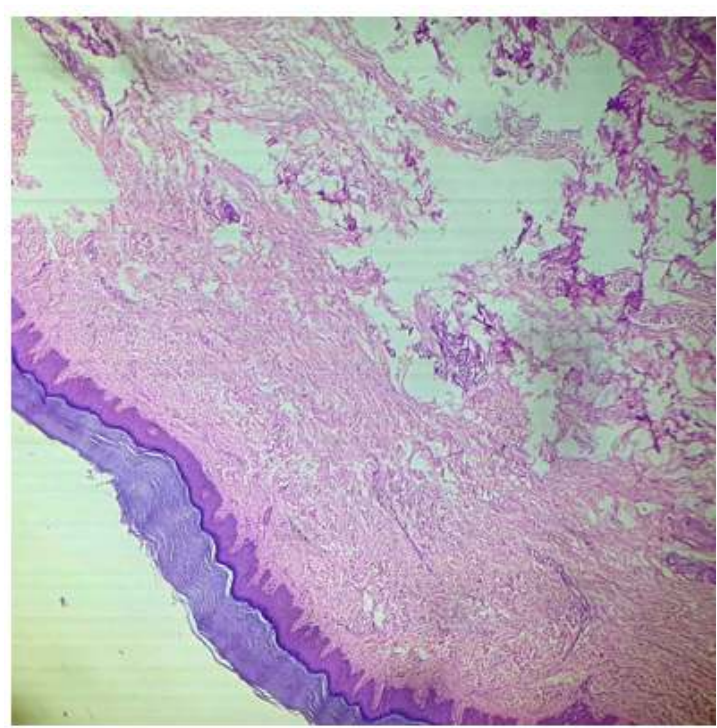

Figure 5: Histopathology showing mature fibro-adipose tissue without any involvement of the nerve sheath

\section{Discussion}

There are 2 types of macrodactyly, static and progressive $^{3}$. In the static type, the growth rate of the enlarged digits is normal whereas in the progressive type, which includes ML, the growth rate of the affected digits is increased but the abnormal growth ceases at puberty ${ }^{3,4}$. Aetiopathogenesis of ML is unknown but hypotheses include lipomatous degeneration, fetal circulation anomaly, extremity bud damage, segmentation anomaly during pregnancy and increased size of affected nerve ${ }^{5}$. Problems are cosmetic and mechanical. In our patient pain was the most important complaint which hampered walking and daily activities. Pain was not because of neural involvement but mostly due to overgrowth of the plantar aspect, which produced dorsal deviation of the affected sole.

Diagnosis of ML can be done by various radiological evaluations such as x-ray, computed tomography (CT) and MRI. X-ray findings include excessive increase in soft tissue and osseous tissue, degenerative joint changes as reduced joint space and subchondral cysts whilst MRI reveals abundant adipose tissue and fibrous thickening of nerves ${ }^{6}$. As digital enlargement stops at puberty, surgical correction depends on the patient's symptoms, age and disease severity ${ }^{5}$. Simple debulking surgery is sufficient in most cases ${ }^{7}$. In our case debulking surgery and amputation of the affected toes was done.

Early diagnosis of ML either by CT or MRI and preventing mechanical complications by prompt surgical management are important. Cosmetic surgery is the best option when the swelling is small. 


\section{References}

1. Gaur AK, Mhambre AS, Popalwar H, Sharma R. Macrodystrophia lipomatosa of foot involving great toe. Foot (Edinburgh) 2014; 24:86-8.

https://doi.org/10.1016/j.foot.2014.03.003 PMid: 24703060

2. Singla V, Virmani V, Tuli $P$, Singh $P$, Khandelwal N. Case Report: Macrodystrophia lipomatosa-Illustration of two cases. Indian Journal of Radiology and Imaging 2008; 18(4):298-301. https://doi.org/10.4103/0971-3026.43844 PMid: 19774185 PMCid: PMC2747455

3. Barsky AJ. Macrodactyly. Journal of Bone and Joint Surgery American Volume 1967; 49: 1255-66.

https://doi.org/10.2106/00004623196749070-00001

4. Celebi F, Karagulle K, Oner AY. Macrodystrophia lipomatosa of the foot: A case report. Oncology Letters 2015; 10(2): 951-3.

https://doi.org/10.3892/ol.2015.3300

PMid: 26622602 PMCid: PMC4509009
5. Tuzuner T, Parlak AH, Kavak A, Alper M. A neglected case of macrodystrophia lipomatosa of the foot in an elderly man. Journal of the American Podiatric Medical Association 2005; 95:486-90. https://doi.org/10.7547/0950486 PMid: 16166469

6. Blacksin M, Barnes FJ, Lyons MM. MR diagnosis of macrodystrophia lipomatosa. American Journal of Roentgenology 1992; 158(6): 1295-7.

https://doi.org/10.2214/ajr.158.6.1590127 PMid: 1590127

7. Sudesh P, Raj N, Kumar R and Parakash S: Macrodystrophia lipomatosa. Foot (Edinburgh) 2012; 22:172-4.

https://doi.org/10.1016/j.foot.2012.02.009 PMid: 22476007 